\title{
The origins of the negative historical representations of burghers in Hungary
}

\author{
Gábor $\mathrm{Czoch}^{\star \dagger}$ \\ Eötvös Loránd University, Faculty of Humanities. Atelier Department for Interdisciplinary History, 1088 \\ Budapest, Múzeum krt. 6-8, Hungary \\ ${ }^{*}$ Corresponding author. Email: czoch.gabor@btk.elte.hu
}

\begin{abstract}
Hungarian historiography needs to review its negative representation of towns and burghers typical of the first half of nineteenth-century Hungary, as Vera Bácskai, a major figure of Hungarian urban history suggested in a paradigmatic paper. Starting from her statements, this article examines the historical narratives of secondary school textbooks and wider historical syntheses of Hungarian history published in the age of Austria-Hungary (1867-1918). The author shows that the burghers' negative image was rooted in the political fights prior to the 1848 Revolution and the emergence of modern nationalism.
\end{abstract}

The work of Vera Bácskai (1930-2018) is of fundamental importance for the history of Hungarian towns and urban society. Although her first publications dealt with the late Middle Ages, most of her later research was dedicated to the urbanization of the eighteenth and nineteenth centuries, and the analysis of the society and economy of certain towns - especially of (Buda)Pest. ${ }^{1}$ She focused on the phenomena caused by the emergence of capitalism in Hungary, and which concerned the transformation and modernization of estate society based on privileges. In order to promote a better understanding of these issues, along with her empirical papers, she regularly published problem-oriented methodological writings, in which she critically reflected on the situation and the results of her field, and proposed new research directions accordingly. The present article is connected to one

\footnotetext{
${ }^{\dagger}$ This study has been implemented with the support of the Hungarian National Research, Development and Innovation Fund, financed under the TKP2020-NKA-06 funding scheme.

${ }^{1}$ Some of Vera Bácskai's papers in English: 'Market areas, market centres and towns in Hungary in 1828', Acta Historica Academiae Scientiarum Hungariae, 26 (1980), 1-26 (with Lajos Nagy); Towns and Urban Society in Early Nineteenth-Century Hungary (Budapest, 1989); 'Jewish wholesale merchants in Pest in the first half of the nineteenth century', in M.K. Silber (ed.), Jews in the Hungarian Economy, 17601945 (Jerusalem, 1992), 40-52; 'Small towns in Eastern Central Europe', in P.A. Clark (ed.), Small Towns in Early Modern Europe (Cambridge, 1995), 77-89; 'Budapest and its hinterland: the development of twin cities', in P.A. Clark and B. Lepetit (eds.), Capital Cities and Their Hinterlands in Early Modern Europe, 1720-1850 (Aldershot, 1996), 183-97. See also P.J. Corfield, 'A conversation with Vera Bácskai: urban history in Hungary', Urban History, 25 (1999), 514-35.

(C) The Author(s), 2021. Published by Cambridge University Press.. This is an Open Access article, distributed under the terms of the Creative Commons Attribution licence (http://creativecommons.org/licenses/by/4.0/), which permits unrestricted re-use, distribution, and reproduction in any medium, provided the original work is properly cited.
} 
of her last articles reflecting such programmatic intentions, published in 2006: 'About the old type of burghers'.

In that article, Bácskai suggested revising the scholarly literature concerned with the pre-1848 burgher class (in Hungary, it was the 1848 Revolution that abolished estate-type privileges). The legal system of the pre-1848 period distinguished between two types of towns in Hungary. Seigneurial towns (called oppidum or, in plural, oppida in Latin legal terminology officially in use until 1844) had limited autonomy; they were in the possession of a landowner and their inhabitants counted as villeins (serfs) in a strict legal sense, although the privileges granted to seigneurial towns ensured their inhabitants a far more favourable status than that of villagers. In comparison, free royal towns, or chartered towns (libera regia civitas), were under direct royal authority. According to pre-1848 legal perceptions, only towns of the latter type were considered 'real' towns with full rights. In addition to the Catholic clergy, the aristocracy and the lower nobility, free royal towns constituted the 'fourth estate' in Hungary. Free royal towns were granted collective privileges as if they had been another category of the nobility. As such, they sent their own representatives to parliament, and were allowed to possess landed property. Inhabitants of royal free towns were not automatically considered burghers; in a strict legal sense, the term applied only to those who obtained burgher rights in a particular town. These rights granted their holders participation in urban political life, and, according to the laws of estate society, only those who possessed burger rights were regarded as full members of the urban community.

As opposed to earlier periods, in the first half of the nineteenth century burghers represented only a minority of urbanites, although their proportion varied from town to town. We do not have precise data on the development of the number of burghers. According to Joseph II's census, burghers accounted for 6 per cent of the population of free royal towns, but here the burgher classification does not correspond exactly to legal status. ${ }^{3}$ According to the data that Bácskai published based on the 1828 tax census, 13.6 per cent of the registered urban population had burgher rights; however, this census did not cover the entire population, hence the proportion of burghers in the total urban population was lower than this. ${ }^{4}$ Finally, in 1843-44, a statement was drawn up for the urban bill debated in parliament, according to which burghers made up 6.8 per cent of the free royal towns, but here data, especially on the urban population, seems to be inaccurate. ${ }^{5}$

\footnotetext{
${ }^{2} \mathrm{~V}$. Bácskai: 'A régi polgárságról', in G. Kövér (ed.), Zsombékok. Középosztály és iskoláztatás Magyarországon (Budapest, 2006), 15-37. The Hungarian terms 'polgár' and 'polgárság' refer to medieval and early modern burghers and their social group as well as 'bourgeois' and 'bourgeoisie' in the modern, nineteenth-century sense. 'Polgár' and 'polgárság thus function in the same way in Hungarian as 'Bürger' and 'Bürgertum' in German.

${ }^{3}$ D. Danyi and Z. Dávid (eds.), Az első magyarországi népszámlálás (1784-1787) (Budapest, 1960).

${ }^{4} \mathrm{~V}$. Báckai, Városok és városi társadalom Magyarországon a XIX. század elején (Budapest, 1988), 177.

${ }^{5}$ According to this statement, in the city of Pest there were 3,432 burghers representing 5.9 per cent of the population, in Buda there were 2,401, representing 6.7 per cent in Pozsony (present-day Bratislava) 1,460, representing 5.6 per cent and in Debrecen 2,401 burghers representing 9 per cent of the total population. T. Dobszay, 'Lakosok és polgárok. A magyarországi városi összlakosság és a polgárok arányának kérdéséhez az 1840-es évek első felében', Fons, 20 (2013), 77-88.
} 
Apart from a few exceptions, Hungarian historiography has depicted burghers in a rather negative manner. This negative image can be briefly summarized as follows: during the first decades of the nineteenth century, the burgher class identified as no more than a few per cent of the population in free royal towns who possessed burgher rights - was a group clinging tenaciously to their long-held privileges. They were retrograde, unable to adapt to the changing economic and political environment. Historical scholarship has argued that the representatives of the old burgher class lacked all sense of a new, capitalist type of entrepreneurship and were stranded in the framework of the guild system. Last but not least, historical literature has also condemned the old burgher class for their foreign especially German - origins. $^{6}$

Bácskai argued, however, that although the above judgements were not completely unfounded, they needed fundamental revision. She insisted that the phrase 'old type of burghers' included in the title of her study should not be used as a mere synonym for those who formally gained burghers' rights in free royal towns. As she pointed out, on the basis of their lifestyles and economic operations, regardless of their actual legal status, numerous citizens of the early nineteenth century may be considered burghers - or bourgeois. Thus, in her interpretation, the phrase 'burgher' cannot be limited to a mere legal category.

The phrase 'old type of burghers' is used in the scholarly literature primarily to make a distinction between burghers and a modern capitalist bourgeoisie. In her study, however, Bácskai provided a detailed argument for reconsidering that distinction. On the one hand, she argued, there had been some - although admittedly only a few - representatives of the old burgher class who could be considered as forerunners of a modern bourgeoisie. On the other hand, although the modern bourgeoisie cannot be derived organically from the old burgher class, in many respects the new, modern bourgeoisie - especially its values - went back to its predecessor. Thus, Bácskai argued, there was a degree of overlap between the old burgher class and the new bourgeoisie, and there was also a degree of continuity between the two categories. The precise charting of the overlaps and continuities, she suggested, required further research, because such investigations had only been done for a few towns. One of the reasons she gave for the relative lack of interest was the fact that most researchers failed to notice that 'the transformation of early nineteenth-century urban societies left a mark on the old burger class too, and, inside that class, led to the emergence of a new group whose members can be considered as precursors of the modern bourgeoisie'. Furthermore, she drew attention to the fact that 'early nineteenth-century authors and the historians whom they inspired paid attention only to guild craftsmen and retail traders

\footnotetext{
${ }^{6}$ For an example of this interpretation, see G. Ránki, 'Die Entwicklung des ungarischen Bürgertums vom späten 18. zum frühen 20. Jahrhundert', in J. Kocka (Hrsg.), Bürgertum im 19. Jahrhundert. Deutschland im europäischen Vergleich, vol. I (Munich, 1988), 247-65. On this problem, see also Á. Tóth, G. Czoch and I. Németh, 'Urban communities and their burghers in the Kingdom of Hungary (1750-1850). The possibilities databases offer for historical analysis', in J. Colson and A. van Steensel (eds.), Cities and Solidarities. Urban Communities in Pre-Modern Europe (London and New York, 2017), 188-207. German-speaking burghers' settlement in Hungarian cities go back to several waves of immigration from the Holy Roman Empire, taking place in the twelfth to thirteenth centuries, as well as in the eighteenth century. For a detailed presentation, see G. Seewann, Geschichte der Deutschen in Ungarn, 2 vols. (Marburg, 2012).
} 
fulfilling local needs, as those individuals formed the majority and constituted the most vocal group within urban society. Innovators remained unnoticed or were simply not considered burghers.'

Vera Bácskai's view can thus be summarized as follows: the negative image of the early nineteenth-century burgher class can be explained partly by the lack of appropriate research, and partly by conceptual and perceptual issues that characterized previous analyses. But there is a third reason as well that I intend to analyse in more detail, namely the fact that historians' interpretations have been greatly influenced by pre-1848 political discourses. In Hungarian historiography, the decades prior to the 1848 Revolution, which brought about the dissolution of estate privileges, are known as the Reform Era. The political debates of that era were led by the liberal nobility, whose representatives were rather critical of burghers. One of the conclusions Bácskai draws is that the critical stance toward the old burgher class, which took shape in the 1830s and 1840s, continued to influence later political discourses, especially the one which prevailed over the late nineteenth and early twentieth centuries (including the inter-war period). It was primarily concerned with the nature and origins of the Hungarian middle class. The latter discourse has already been the object of detailed analysis. ${ }^{8}$ For a better understanding of why burghers were presented in such a negative historical light, my purpose is to investigate the forms in which the historical memory of towns and burghers of the Reform Era appeared in the second half of the nineteenth century, at a time when the need for creating a uniform, Hungarian-spirited middle class often emerged in political discourses as a national responsibility of utmost importance. In order to complete this task, first we have to recall briefly the contemporaneous assessment of towns and burghers.

\section{Debates on towns and burghers in the first half of the nineteenth century}

Debates about Hungarian towns and burghers intensified from the second half of the 1820s, although they had started earlier. Dissatisfaction with the backwardness of towns and burghers and the political standing of towns were the fundamental topics. Quite often, the situation of Hungarian towns was criticized from the perspective of an idealized Western European pattern. Concerning the poor economic status of towns, we should note one of the first comprehensive descriptions of Hungary outlining its geography, economics, population, society and political structure by Martin Schwartner at the end of the eighteenth century. He talks in a critical manner about the small fraction of the Hungarian population living in towns, observing that the rate is 'frightfully low in comparison not only with the industrially advanced, urbanized France' but 'even worse than the rates found in poor Sweden'. On top of that, he records that the majority of townsfolk made their living from agriculture, and even craftsmen and merchants supplemented their income with agricultural activities. He also points out the contradiction

\footnotetext{
${ }^{7}$ Bácskai, 'A régi polgárságról', 24, 29.

${ }^{8}$ G. Gyáni, 'Polgárság és középosztály a diskurzusok tükrében’, Századvég, 7 (1997), 30-45; G. Kövér, 'A magyar középosztály-teremtés programjai és kudarcai. Fogalomtörténeti áttekintés a reformkor végétől a nagy válság kezdetéig’, in Kövér (ed.), Zsombékok, 77-160.
} 
that more than half of the settlements legally qualified as towns - namely the free royal towns - had a population of less than 5,000, while there were seigneurial towns that surpassed most free royal towns both in their population numbers and their economy. ${ }^{9}$

These contradictions in the contemporary settlement system were due to two main reasons. One was the changes taking place in the country's economic standing. Prior to the eighteenth century, Hungarian urbanization had been driven by precious-metal mining, and long-distance trade with the Holy Roman Empire and Poland. By the middle of the eighteenth century, however, both activities had lost their significance. The yield of mines in the Carpathians had dropped. The Viennese court's protectionist economic policy, especially the new mercantilist toll system Maria Theresa introduced in 1754, isolated the country from its previously important foreign markets. In parallel, urban development started to be impacted by new factors, primarily the distribution of agricultural products within the borders of the empire. Due to this restructuring, the eighteenth century saw the impoverishment of towns with royal privileges that had gained their prosperity from mining or foreign trade. Therefore, their development was halted. At the same time, the agricultural centres in the country's middle regions started to grow fast. However, most of them had only seigneurial legal status.

These changes are well illustrated by comparing data from national censuses for the period under study. The first census covering all the inhabitants of the country was ordered by Joseph II in 1784. The next similarly complete census took place as late as 1850, after the defeat of the Revolution and the War of Independence in 1848-49. A further census, important for this study, was conducted in 1828. Although it only covered the tax-paying population, it included a question concerning where peasants sold their products and in which market they obtained the manufactured goods they needed. Based on this data, Vera Bácskai and Lajos Nagy managed to determine the market catchment area of each settlement. In her next project, Bácskai carried out a thorough examination of the contemporary market centres, which focused on settlements that played a central role and had urban functions. ${ }^{10}$ These sources enable us to examine the peculiarities of Hungarian urbanization by comparing three indicators, namely population size, legal status and, for 1828 , the central role of settlements. ${ }^{11}$

Looking at the figures for the most populous settlements, namely those with more than 10,000 inhabitants (21 in 1784, and 56 in 1850), it appears that demographic urbanization was mainly concentrated in large grain-producing regions: in 1784, 9 of the 21 large settlements were situated in the Great Plain, while by 1850, this number had increased to 39 out of 56. However, only 6 of them were free royal cities by status. Of the formerly prosperous mining towns in the northern mountainous areas, only Selmecbánya (Banská Štiavnica), with a population of nearly 19,000 , was among the largest settlements at the end of the eighteenth century.

\footnotetext{
${ }^{9}$ M. Schwartner, Statistik des Königreichs Ungarn (Ofen, 1809), 163-7.

${ }^{10} \mathrm{~V}$. Bácskai and L. Nagy, Piackörzetek, piacközpontok és városok Magyarországon 1828-ban (Budapest, 1984); and Bácskai, Towns and Urban Society.

${ }^{11}$ G. Czoch, G. Szabó and L. Zsinka, 'Változások a magyar város- és településrendeszerben 1784 és 1910 között', Aetas, 8 (1993), 113-33; V. Bácskai, Városok Magyarországon az iparosodás elött (Budapest, 2002), 83-122; Tóth, Czoch and Németh, 'Urban communities', 203-4.
} 
By the middle of the nineteenth century, however, the population of Selmecbánya had been halved, meaning that by that time all mining towns were below 10,000. Another example of a mining town in the valley of the Garam (Hron) River in the Carpathian Mountains is Körmöcbánya (Kremnica), once famous for its gold mining, where one of the most important mints of the Kingdom of Hungary had operated since the fourteenth century. Here, the census ordered by Joseph II showed only 5,185 people, and in neighbouring Besztercebánya (Banská Bystrica), which used to be a mining centre of outstanding importance, there were only 5,033. By the time of the 1850 census, however, the population of the two cities had decreased even further: to 4,455 and 4,055 , respectively.

Overall, between the end of the eighteenth and the middle of the nineteenth centuries, the proportion of free royal towns among the settlements with a population of more than 10,000 dropped significantly: in 1784, 15 out of the 21, and in 1850, only 22 out of the 56, i.e., less than half of the most populous settlements were free royal towns. At the same time, 18 of the 47 free royal towns had a population of less than 5,000. The three smallest free royal towns, Ruszt (Rust), Libetbánya (Lubietová) and Zólyom (Zvolen), numbered 1,244, 1,550 and 1,665 respectively according to the 1850 census. The predominance of market towns is also apparent in the light of Bácskai's ranking of cities according to their central role. She shows that in 1828, 57 settlements corresponded to the criteria of cities and towns with a central role. Of these, only 22 were free royal cities by status. In other words, only half of the free royal cities, the 'real cities' in contemporary legal terms, proved to be genuine cities. As Bácskai rightly pointed out, the legal concept of the city was increasingly separated from the functional one.

These contradictions are not fully explained by mere economic factors. The discrepancies of the settlement system were also of a political nature. Although several free royal towns had lost their significance, according to the legal framework of estates, their previously acquired privileges could not be taken back, as this would have invalidated the entire system of privileges. On the other hand, the noble class strongly opposed bestowing chartered privileges on the fast-growing manorial towns. From the end of the seventeenth century, the aim of the nobility was to prevent the multiplication of free royal towns. Following the recapture of Buda from the Ottomans (1687), the first Hungarian parliament of estates, as part of the agreement between the ruler and the estates, declared that in addition to a royal charter, parliament's approval was also necessary in order to gain privileges as a free royal town. Manorial towns provided significant incomes to their landowners, thus their ascent to chartered status would have caused substantial financial losses to their previous owners. However, in addition to their economic interests, the nobility also opposed raising the number of chartered towns for political reasons. This was because free royal (chartered) towns (as opposed to towns with seigneurial status) had the right to be represented in the lower chamber of parliament, along with delegates of the lower clergy, and the chosen envoys of the nobility of the counties. (The higher chamber included delegates of the aristocracy and the high clergy.) The nobility was afraid that increasing the numbers of urban delegates would endanger their determining role in the lower chamber. During the eighteenth century, seven additional seigneurial towns received chartered status, but from 1790 until the 1848 Revolution that abolished the constitution of estates, the 
nobility managed to block the issue of further royal charters in the lower chamber. ${ }^{12}$

Not only did the nobility of the counties try to protect their majority against town delegates in the lower chamber, but their aim was also to limit royal influence throughout parliament. This was due to their view of urban delegates as servants of Viennese court policies. This conviction was completely unfounded. In fact, the absolutist Habsburg government sought to limit traditional urban autonomy from the end of the seventeenth century. Economic activity and the election of officials were put under strict supervision. As a result, by the first half of the nineteenth century, senior town magistrates could only be elected from a list of candidates previously approved by royal commissioners. Moreover, only these officials had the right to choose parliamentary envoys, rather than the entire burgher community.

The debates concerning the situation of towns and burghers fitted into the framework of a more general political struggle between the Viennese court and the Hungarian estates becoming more and more intense from the 1820s. The ultimate stake was the modernization of the country, as well as the overall transformation of its political structure. ${ }^{13}$ In the course of these debates, the low rate of the urban population and the economic weakness of towns appeared as indicators of the country's general underdevelopment, contributing to the dissatisfaction with towns and their burghers. The negative assessment of towns was also reinforced by the nobility's previously noted age-old criticism that towns were increasingly subject to central governmental supervision. Moreover, in the eyes of the liberal opposition of intellectual aristocrats who were gaining increasing influence from the second decade of the nineteenth century, the royalism of towns was seen as a potential obstacle in the way of the country's transformation along liberal principles.

The parliament of 1825-27 was a turning point in the debates with the Viennese court concerning political-economic reforms. The events of this parliament had a crucial impact on the issue of towns, which constituted a part of these debates. In the course of the parliamentary dispute, delegates of the nobility ensured that in the lower chamber urban envoys could not keep their individual votes - instead, the 47 chartered towns had one unified vote, thus practically excluding them from decision-making at a time when voting was just starting to become general practice in the parliament of estates. ${ }^{14}$

Debates concerning the towns' political standing - in whose course the different endeavours of the Viennese court, the nobility and the towns clashed - dragged on until the 1848 Revolution. ${ }^{15}$ The court's centralizing policy sought to keep urban governance under the strictest possible supervision. This was expected to strengthen the forces loyal to the king, and to make government administration

\footnotetext{
${ }^{12}$ On these problems of Hungarian urbanization, see Bácskai, Városok Magyarországon az iparosodás elött, 83-122.

${ }^{13}$ See, for example, G. Vermes, From Feudalism to Revolution: Hungarian Culture and Politics in the Habsburg Monarchy, 1711-1848 (Budapest, 2014).

${ }^{14}$ For a recent summary about the parliamentary voting rights of towns, see T. Dobszay, $A$ rendi országgyülés utolsó évtizedei, 1790-1848 (Budapest, 2019), 217-23.

${ }^{15}$ See, for example, S. Szücs, A városi kérdés az 1832-36. évi országgyülésen (Budapest, 1996), 9-29; G. Czoch, 'Nemzetfelfogások a városi kérdés reformkori vitáiban', in Z. Horváth and J. Rada (eds.), Társadalomtörténeti tanulmányok Tóth Zoltán emlékére (Miskolc, 2017), 168-77.
} 
more effective. The representatives of the nobility regarded urban administration with hostility. They accused the urban political elite of corruption and nepotism and in many cases, these accusations were well founded. The governance of towns was indeed centralized in the hands of a narrow oligarchy, which only represented a small circle's interests, rather than those of the entire burgher society. In addition, however, the nobility was dissatisfied with the towns mostly because, as we have seen, they thought that local governments were under the court's overwhelming influence; thus, they tried to loosen the dependency between the central government and the towns. The nobility's political spokesmen did not exclude renegotiating the issue of town representatives' parliamentary votes. However, the majority could only imagine this in the framework of a comprehensive urban reform. This extensive reform would have limited towns' dependence on the central government and would have transformed urban administration in a way not to be concentrated exclusively in the hands of a court-loyal oligarchy.

Finally, urban representatives wanted to restore the towns' traditional autonomy, thus they supported the nobility in decreasing the influence of the central government. Most towns did not reject the concept of transforming urban administration either. However, their utmost aim was to regain their individual voting rights, which in their thinking was their inherent legal privilege.

During the following parliaments in $1832-36$ and $1839-40$, there were serious debates over the situation of towns. However, the detailed formulation of a comprehensive urban reform that had been increasingly called for could only start upon royal approval during the Diet of 1843-44. The fairly detailed bill mainly reflected the liberal noble opposition's ideas. The proposal was to place municipal government on the foundations of democratic representation. It determined the separation of the judiciary and the executive power, envisaged the creation of a municipal board of representatives, and extended to the entire bourgeoisie the rights of electing town representatives and other officials. Although the acquisition of burgher rights was based on occupational and property criteria, the conditions were formulated in a manner that citizenship would be available to a wide range of urban inhabitants, including Jews, who had previously been excluded from such privileges. The bill envisaged a total of 32 assembly votes for the chartered towns in the lower chamber of parliament, expecting to double the counties' 52 votes at the same time. These votes were to be divided among the 47 towns according to the size of their population. Ultimately, the bill did not pass into law due to the king's opposition, but the related debates shed a sharp light on the contemporary assessment of towns and their burghers. ${ }^{16}$

Overall, these discussions took place in an atmosphere rather hostile to towns. The nobility's representatives voiced all the previously listed points of criticism. In this discourse, it was always emphasized that most burghers in chartered towns were of 'foreign' rather than Hungarian descent, primarily German-speaking, as opposed to the mainly Hungarian population of the seigneurial towns in the central agricultural regions of the country, which were prospering

\footnotetext{
${ }^{16}$ G. Czoch, 'A városok szíverek.' Tanulmányok Kassáról és a reformkori városokról (Pozsony, 2009), 228.
} 
due to the grain trade. ${ }^{17}$ Naturally, these were simplistic statements about the ethnic composition of urban populations, made in the heat of political debate. Not all the market towns of the Great Plain were exclusively Hungarian, in the same way as the population of free royal towns was not linguistically or ethnically homogeneous either. We have no precise data about the contemporary ethnic composition of towns, but there is no doubt that a significant part of the townspeople, and primarily the burghers of smaller mining and trading communities impoverished by the first half of the nineteenth century, were Germans. For example, Pest-Buda (the name for Budapest before its unification), acquiring a central role in the country by the middle of the nineteenth century, in 1850 had a population that was 49 per cent German (and only 31 per cent Hungarian); 71 per cent of the inhabitants of Pozsony (Bratislava), the town hosting the parliaments, were also of German origin (with only 6 per cent Hungarians, plus 10 per cent Slovaks and 13 per cent Jews). ${ }^{18}$

When the issue of the bourgeoisie's ethnic composition was discussed in the early nineteenth century, the image presented was very different from that in the middle of the century. In his book, Martin Schwartner on the one hand noted that 'Hungarian people dislike urban lifestyles, as open fields are befitting their inclinations and their love of freedom much more'; on the other hand, he wrote appreciatively about German burghers, as they revived urban industry and commerce, and also laid down the foundations of mining. Schwartner, who was himself also of German burgher descent, added that German people 'quickly adapted to the national attire of Hungarians', indicating that he felt the need to underline their loyalty towards the Hungarian people. ${ }^{19}$

However, during later debates concerning towns, the exact opposite was emphasized. For example, at the 1832-36 Diet, the nobility protested against having an urban delegate among those validating the minutes of the lower chamber sessions. There were three reasons. First, because towns depended on the government, secondly, because due to the election procedure, their delegates could not represent the entire burgher class, and thirdly, because their national consciousness was regarded as inadequate. ${ }^{20}$

By the 1840s, debates concerning towns focused particularly on the ethnic composition of the bourgeoisie. This gave several county delegates reason to oppose increasing the power of towns in parliament. They argued that it would pose a

\footnotetext{
${ }^{17}$ In the following paragraphs, I rely on my former, more detailed presentation of this debate, except for the problem of the coeval multiple concepts of nation which I did not discuss in that paper: G. Czoch, 'The question of urban citizens' national identity in mid-nineteenth-century Hungary', East Central Europe/ L'Europe du Centre-Est: Eine wissenschaftliche Zeitschrift, 33 (2006), 121-39.

${ }^{18}$ D. Dányi, Az 1850. és 1857. évi népszámlálás (Budapest, 1993), 62. Even though officially Pest and Buda were administered as separate cities until 1873 , the name Budapest occurs several times as early as the 1840s. The 1850 census was the first to ask about the population's national composition, and unlike later censuses, the question was about individuals' national affiliation rather than their mother tongue. However, only the aggregate data of the census were published. The detailed data of each settlement, with the exception of the five largest administrative centres (Pest-Buda, Sopron, Pozsony/Bratislava, Kassa/Košice, Debrecen and Nagyvárad/Oradea) were not published, and in the late 1850s most of the census material was destroyed.

${ }^{19}$ Schwartner, Statistik, 118-24, 129-32.

${ }^{20}$ Quoted by S. Szőcs, A városi kérdés az 1832-36. évi országgyülésen (Budapest, 1996), 10.
} 
danger to the country if they were to give more parliamentary votes to towns while Hungarians only represented a minority of the burghers. Thus, as debates in parliament suggest, by the 1840 s, the nobility attributed the political unreliability of towns not only to their dependency on the government, but mainly to their burghers' foreign descent. Moreover, in the course of the 1843-44 parliament, it was an increasingly shared opinion in the debates that all the problems related to chartered towns could ultimately be traced back to the their burghers' foreign origins. In order to give even stronger emphasis to this critique, Hungarian towns were contrasted with the idealized role that cities were believed to have played in the nationbuilding processes of large European countries. As one of the county envoys declared:

What is the reason behind our cities not having been able to attain foreign levels of wealth, commerce, cultivation, political operation, and respect, not even with the support of the court?...It must be nationality, since in Germany, Italy, France, England and Spain, cities, nobles and common people were united in their nationality; furthermore they were made conscious of the sacred sense of nationality, while in our homeland cities form isolated islands. Never, or at least with great difficulty, would they adapt to the Hungarian nationality, which is the reason for the depressed status of our cities. ${ }^{21}$

These debates about the 1843-44 bill and about the way the standing of towns was interpreted were in fact about whether towns could be considered as part of the nation at all, and, if so, to what extent. The answers to this question reveal that there existed several simultaneous concepts of the nation at the same time, however carrying different weights. Whichever approach was taken, the outcome was altogether unfavourable for the towns. ${ }^{22}$

Critics emphasizing burghers' German origin witnessed the emergence of a new, ethnolinguistic approach to the concept of nation according to which burghers whose mother tongue was not Hungarian could only be fully recognized parts of the nation through their complete assimilation to Hungarians. According to the definition of the medievalist Jenö Szücs, one of the most comprehensive scholars to study the medieval antecedents and the formation of Hungarian national identity, the main innovation in the concept of the modern nation in comparison with the medieval understanding is that it correlates the political community and political loyalty with ethnic origin. ${ }^{23}$ It was a telling example of this phenomenon that

\footnotetext{
${ }^{21}$ Parliamentary speech by Péter Géczy, Zólyom County, in 1843-44. évi országgyülés. Magyarországi Közgyülések naplója a tekintetes Karoknál és Rendeknél (Rendi Napló), 6 vols. (Pest and Pozsony, 1843-44), vol. III, 106-7.

${ }^{22}$ On the level of the Habsburg Empire as a whole, Pieter M. Judson identifies five different conceptions of the nation in public discourse at the end of the eighteenth century. See P.M. Judson, The Habsburg Empire. A New History (Cambridge, MA, and London, 2016), 85-9.

${ }^{23}$ J. Szücs, Nation und Geschichte. Studien (Budapest, 1981). On Szücs's theory, see C. Jaffrelot, 'For a theory of nationalism', in A. Dieckhoff and C. Jaffrelot (eds.), Revisiting Nationalism. Theories and Processes (New York, 2006), 43-4. From the vast literature on this subject, let me refer only to the excellent studies by R.J.W. Evans, Austria, Hungary and the Habsburgs. Essays on Central Europe, c. 1683-1867
} 
certain representatives of the nobility traced back the bourgeoisie's political standing and loyalties to its ethnic composition.

However, in the debates concerning towns, manifestations of the medieval concept of the nation are also present: in the idea of Natio Hungarica, ethnicity played no role at all. The 'Hungarian Nation' comprised those who had political rights, or in other words, those who belonged to the privileged estates, regardless of their ancestry. Therefore, from 1606, in addition to the clergy, the aristocracy and the nobility, the framework of the Natio Hungarica - theoretically - included chartered towns as well as a legally accepted fourth estate. The nobility, however, considered themselves as the foremost representatives of the Natio Hungarica. Whenever they tried to protect their privileges against the absolutist policy of the Viennese court, they appealed to the protection of the liberty of the 'Hungarian Nation'. According to this approach, the towns under the influence of Viennese policies abandoned the nobility in the battle for preserving the freedom of 'the nation'. As one of the envoys declared during the 1843-44 parliament, 'royal towns, these establishments restricted in their freedom, relate to the nation and national liberty as hostile, alien elements'. However, this envoy explained the sense of strangeness with reference to the problematic situation of burghers among the estates, rather than their nationality. In his opinion, although legislation elevated towns from the ranks of common people (as chartered towns composed a collective person of the nobility, thus enabling them to be landlords of villages), the nobility never actually accepted them as such. ${ }^{24}$ Thus, according to this approach, the relations of chartered towns with the nation seemed questionable even in the sense implied by the concept of Natio Hungarica.

Debates in parliament included a third type of national approach as well, the roots of which go back to the seventeenth century, gradually spreading mostly among German and Slovak-speaking burghers and intellectuals. This approach was built on the idea of a common homeland, a shared territorial attachment, regardless of ethnic and social differences. Thus, in this interpretation 'Hungarus' meant a subject of the Kingdom of Hungary. The best example is how the outstanding scientist-polymath, Mátyás Bél/Matej Bel (1684-1749) formulated his identity: 'lingua Slavus, natione Hungarus, eruditione Germanus'. ${ }^{25}$ In the course of the 1843-44 debates around the urban bill, urban representatives who felt that the critical remarks concerning burghers' nationality mostly referred to them, responded by pointing out their services to the country, as well as their patriotism. Thus, in contrast to the ethnolinguistic national approach, they referred to their concept of nation based on territorial ties. However, in the political debates concerning the principle of individual votes in parliament, they also identified with the nobility's ethnolinguistic arguments, insisting that the burghers of their towns

(Oxford, 2006), and to the work of Pieter M. Judson, which gives a new interpretation of the issues of nationhood and nationalism in the Habsburg Empire: Judson, The Habsburg Empire.

${ }^{24}$ Speech by Antal Radvánszky, Zólyom County, Rendi Napló, vol. III, 92.

${ }^{25}$ A. Miskolczy, 'A hungarus tudat a polgári-nemzeti átalakulás sodrában', Magyar kisebbség, 17 (2012), 166. On this concept, especially from the Slovak point of view, see A. Maxwell, 'Multiple nationalism: national concepts in nineteenth-century Hungary and Benedict Anderson's "Imagined Communities", Nationalism and Ethnic Politics, 11 (2005), 385-414. 
'demonstrate their love of their native country's language by eagerly learning and spreading [the use of] Hungarian themselves'. ${ }^{26}$

The burghers' chief argument for exercising their political rights, nevertheless, was founded on their ancient privileges. According to the constitution in force, they argued, all free royal towns were granted the same rights, including the individual parliamentary vote, and all free royal towns constituted communities of privileged burghers. This identification of the town with the burghers' community proved to be increasingly difficult by the middle of the nineteenth century when, as seen earlier, privileged burghers constituted a minority of urbanites. Nevertheless, for the political elite of free royal towns the burghers' right remained the sole distinctive criterion, regardless of their ethnicity or the languages they spoke. As a logical consequence, according to this conception of urban society, 'foreigners are all those who have not received the title of burgher' - to give the example of the charter in the free royal town of Kassa/Košice - that is, without considering their national affiliation or geographical origin. ${ }^{27}$

In the parliamentary debates, the urban delegates repeatedly stressed the importance of this dividing line. For them, being a burgher was a recognition, an honour. One of them even stated that in his town it was humiliating for a burgher's daughter to marry a non-burgher. ${ }^{28}$ According to the urban delegates, a burgher had to be an independent person with sufficient wealth and income to secure him material independence. This allows him to form an independent political opinion, as the burgher status entailed political rights.

For the same reason, it was also considered important that the burgher should be educated, that is, he should at least be able to read and write. Furthermore, burghers had to be well-behaved and observe high moral standards. Finally, a burgher had to belong to a Christian denomination. In this vein, the towns almost unanimously rejected the possibility of Jews assuming burgher rights. Thus, according to the value system that emerges from the parliamentary speeches given by representatives of burghers, a city dweller's social status was determined not by his ethnic and national affiliation, but primarily by his economic standing, denominational affiliation and, above all, by his legal status. Therefore, the internal social division and social relations of the otherwise multi-ethnic cities will be misunderstood if we

\footnotetext{
${ }^{26}$ The speech by Antal Markovics, Bártfa (present-day Bardejov, Slovakia) Rendi Napló, vol. III, 105. We do not have a comprehensive picture of the ordinary linguistic reality of multi-ethnic cities at the time, but the following description from 1846 may be extrapolated: 'The linguistic chaos of Babel characterizes the life in Eperjes (Prešov). Some mix four languages into one (e.g. "Servus humillimus, édes uram bátyám, ta jakzse prosli, csi na forspont, csi na eigene Gelegenheit?" [At your service, my dear sir, how did you come, in a cart or using another vehicle?]; or "Iczme pajtáskám, spaczirovatz versus Calvarienberg" [So, my friend, we walk towards the hill of the Calvary])', Magyarföld és népei eredeti képekben. Föld-és népsimei, statistikai és történeti folyóirat, 1 (1846), 3, 5. Linguistic diversity appeared in literacy as well. Although the language of urban administration officially changed from Latin to Hungarian from 1841, an examination of the administrative language of the city of Košice shows that in the 1830s and 1840s officials used Latin, German and Hungarian alternately; in addition, some of the documents submitted to the city were in Slovak. See T. Kőmíves, 'Kassa belső nyelvhatárai a 19. század első felében', in I. Dobos and S. Bene (eds.), Határátlépések (Budapest, 2011), http://mek.oszk.hu/09700/09720/html/index.htm\#b396, accessed 15 Dec. 2020.

${ }^{27}$ Czoch, 'A városok sziverek', 123.

${ }^{28}$ Speech by János Kilvády, Breznóbánya (present-day Brezno, Slovakia), Rendi Napló, vol. II, 349.
} 
attach excessive importance to their linguistic and ethnic composition, even in the years immediately preceding 1848 .

For a better understanding of contemporary burghers, the critique of the traditional national approach of historiography, advanced by Pieter M. Judson, Tara Zahra and others, proves much more promising. ${ }^{29}$ By introducing the concept of 'national indifference', they warn against attaching primary importance to national identity in the everyday activities of social agents. However, the concept of national indifference, as Judson has pointed out, is 'only useful relative to the almost universal power of ideas of nationhood'. ${ }^{30}$ As the above analysis has shown, it was from the mid-1840s onwards that the ideas of nationhood gained dominance in the discourse on cities and burghers in the Kingdom of Hungary. For further research, therefore, the question to be examined from the point of view of national indifference would be how far national political debates had an impact on specific local urban communities.

Judson's second related suggestion is 'to think situationally about nationhood rather than in terms of essences and identities' ${ }^{31}$ This interpretation seems to be appropriately substantiated by the speeches of members of parliament in most German-speaking cities about the 1843 urban bill: in order to recognize their political rights, they eagerly asserted their national allegiance. As a result of the political debates at a national level, towns were forced to position themselves in relation to nationhood. Under the impact of emerging Hungarian nationalism, and also as a self-defensive reaction, in the parliamentary discussions they adopted the reasoning of the nobility by stressing the burghers' patriotism.

However, these arguments did not ease the hostility towards towns. By the midnineteenth century, the ethnolinguistic national approach and nationalism had become dominant among the nobility, determining the political discourse. By the beginning of 1843, Lajos Kossuth, the central figure of the liberal noble opposition, argued with reference to the matter of urban reform that the nobility would deservedly play a leading role in 'the immense work of national rebirth', but for this they needed 'an individual, constitutional middle-class...in the lack of which, our nation ha[d] no future'. ${ }^{32}$ However, he also bitterly pointed out that this middle class did not exist, because it had not yet been created. Indirectly, this statement also reflected Kossuth's opinion about the contemporary bourgeoisie.

\section{The image of burghers in secondary school textbooks}

In order to analyse how later historical memory was influenced by the political discourse of the Reform Era, my research is narrowed down to two important areas shaping collective memory. On the one hand, I have investigated the textbooks

\footnotetext{
${ }^{29}$ See Judson, The Habsburg Empire; P. Judson, 'Nationalism and indifference', in J. Feichtinger and U. Heidemarie (eds.), Habsburg neu Denken: Vielfalt und Ambivalenz in Zentraleuropa.30 kulturwissentschaftliche Stichworte (Vienna, 2016), 148-55; T. Zahra, 'Imagined noncommunities: national indifference as a category of analysis', Slavic Review, 69 (2010), 93-119. For a general overview of the ongoing debates, see 'Discussion forum: the vanishing nineteenth century in European History?', organizers K. Hagemann and L. Simone, Central European History, 51 (2018), 611-95.

${ }^{30}$ Judson, 'Nationalism', 154.

${ }^{31}$ Ibid., 153.

${ }^{32}$ Quoted by Kövér, 'A magyar középosztály', 77.
} 
used in secondary school history teaching for students between the ages of 10 and 18 years, while on the other, I have surveyed the major undertakings on Hungarian history published up to the turn of the nineteenth and twentieth centuries, which addressed among other topics the first half of nineteenth century. The textbooks reviewed were the officially licensed schoolbooks. ${ }^{33}$

The primary observation arising from this research is that none of the textbooks deal with the towns and burghers of the Reform Era in much detail. They discuss the development of trade and industry during the first half of the nineteenth century in a brief and general manner, but even when doing this, their main focus is on introducing related regulations. They do not present a detailed description of towns or the situation of the bourgeoisie. There are a few textbooks that may be considered exceptions, but they differ only in acknowledging the contemporary prosperity of Pest and its transformation into the capital of Hungary.

As the original survey yielded no other substantial result than the fact that information in textbooks was usually scant, I decided to extend my scope to preceding periods of history. My objective was to find out how, in what context and concerning which eras contemporary secondary school textbooks dealt with the history of Hungarian towns and burghers. I found that in line with the dominant trend in contemporary historiography, textbooks almost exclusively dealt with the history of the state, while the presentation of historical processes was divided according to the reign of monarchs. Owing to this perspective, there are no more than a few sporadic lines about towns and burghers. Textbooks typically mention the primarily German and Flemish immigration of settlers under King Géza II (1141-62), and Béla IV (1235-70), a brief introduction of the town-supporting policies of Charles I of Anjou (1308-42) and his son Louis I 'the Great' (1342-82), and the establishment of the guild system under the latter. Concerning the eleventh- to the fifteenth-century period, the prosperity and development of towns is emphasized. Regarding the sixteenth and seventeenth centuries, the age of Turkish wars and Ottoman rule, the secondary school curriculum does not discuss towns and their burghers to any significant extent. The next era in which towns are noted is the eighteenth century: textbooks acknowledge their development due to the restoration and consolidation following the Ottoman rule in the first half of the century; however, prosperity seems to have been halted during the reign of Maria Theresa. Textbooks univocally refer to the Viennese court's economic policy as the reason for this recoil and relapse, while they also explain that the new mercantilist toll system, introduced progressively from 1754, had a harmful effect on Hungary, withering domestic industry and trade, thus towns as well.

However, in addition, there is another strong general theme running in the textbooks concerning towns and burghers - the emphasis on their foreign origins. In this regard, there are minimal differences between publications. The Royal Court-funded settlements - most of whose inhabitants came from the area of the

\footnotetext{
${ }^{33}$ I compiled the list of textbooks included in the survey based on the catalogues of the National Educational Library and Museum: K. Bakonyi, M. Sasi and J. Tóthpál (eds.), Középiskolai tankönyvek 1868-1948 (Budapest, 1989). These were Hungarian textbooks. In 1904, there were 70 textbooks by 23 authors (with 4 joint authors amongst them) officially licensed for the different kinds of secondary schools. See also M. Unger, A történelmi tudat alakulása középiskolai tankönyveinkben a századfordulótól a felszabadulásig (Budapest, 1976).
} 
Holy Roman Empire - are uniformly considered as positive events, highlighting the role of these burghers in the prosperity of domestic industry and trade. Some remarks suggest that the colonists brought along Western culture, which served to educate the Hungarian population. According to these interpretations, as time passed by, at least up to the time of the Ottoman invasion, the populations of these towns were starting to adapt to Hungarian habits. Thus, the authors who discuss the advantageous effects of colonization on medieval Hungarian culture and education induced by the establishment of towns attribute this phenomenon to the fundamental merging of towns and their environment, more precisely to the assimilation of urban burghers. However, for the period after the Ottoman invasion, the authors also stress the seclusion and alienation of towns and burghers. Thus, in their view, the creation of towns was the beginning of a positive and promising process for the entire country, which unfortunately came to a stop later.

At the same time, most textbooks point out that these towns and their burghers segregated themselves from the rest of the domestic population and kept their habits and traditions. As one of the authors, Pál Király, states in his 1897 textbook that contained an appreciative foreword by Sándor Szilágyi, one of the most influential historians: 'Their effect on our nation converged to zero, their influence is mostly seen in economic aspects. ${ }^{34}$ The standpoint of most contemporary textbooks is well illustrated by a statement found in the section discussing the eighteenth century: 'The institution of towns hardly fits into the life of the nation (yet). As for now, their citizens are mostly foreign speakers, Germans and Slovaks, with only a small minority being Hungarians.' Later, following the introduction of the legal status and internal structures of towns, he briefly pronounces that ' $[t]$ he real strength of the nation was the nobility of the counties'. ${ }^{35}$

In summary, what did school-leaving students, who, according to the shared view of the second half of the nineteenth century, were seen as future members of the middle class, actually learn about the development of Hungarian towns and the bourgeoisie; what did they have to give account of at the end of their secondary school studies? To answer this, we can cite the synoptic theses printed for the schoolleavers' final exam. ${ }^{36}$ According to these summaries, towns and their burghers mostly consisted of German immigrants, who at the beginning might have made a positive impact on the domestic economy, but later segregated themselves from the natives, using the privileges they had received from the ruler. Thus, as this formulation implies, they in fact did not belong to the nation. The development of the towns is considered to have been completely stagnant due to Ottoman rule, and especially to the Habsburg toll policies of the eighteenth century. The economic importance of towns, and their political significance, is presented as having dwindled. Because burgers were seen as having been placed under the influence of the Royal Court, they also met with the aversion of the nobility - whom the textbooks introduce as the main protagonists of national interests. Thus, according to the textbooks and their overly simplified presentation, the history of towns and

\footnotetext{
${ }^{34}$ P. Király, Magyarország története. Középiskolai felső osztály (Budapest, 1897), 87.

${ }^{35}$ Ibid., 98.

${ }^{36}$ A. Benisch (ed.), Érettségi összefoglaló tételek a magyar történelemböl. Középiskola (Pécs, 1911).
} 
the bourgeoisie in Hungary is not connected, or is hardly connected, to the history of the nation.

\section{Towns and burghers in greater historical syntheses}

The second part of my analytic survey deals with the syntheses of Hungarian history that cover the first half of the nineteenth century and were published before the turn of the twentieth century. Therefore, my survey includes the works of Mihály Horváth, Béla Grünwald's book entitled The Old Hungary 1711-1825 (A régi Magyarország 1711-1825) published in 1888, the ninth volume of the prestigious 10-volume collective edition entitled The History of the Hungarian Nation (A magyar nemzet története) published in 1897, and finally Ignác Acsády's The History of the Hungarian Empire (A magyar birodalom története), published in 1903-04.

As we might expect, there are no significant differences between the images of towns and the bourgeoisie in official textbooks, on the one hand, and the representations unfolding in academic works, on the other. The primary observation worthy of notice is that the percentage of content dedicated to the subject in the middleschool textbooks and the academic publications on history is similar: towns and burghers only appear in an episodic manner. The difference is that academic works obviously provide a more complex and sophisticated evaluation of the historical role of towns, drawing some more general conclusions about their role in Hungarian history.

First, the works of Mihály Horváth are examined not only to follow a chronological order, but also because of their impact on future interpretations and collective historical memory. ${ }^{37}$ An intellectual committed to civic and urban development, Horváth did not personally participate in the political struggles of the Reform Era, but welcoming any change due to his liberal convictions, he tried to promote the practical application of the reforms through his academic activity. His brief but decisive political engagement, which strongly influenced his own future, dates back to the last months of the 1848-49 Revolution, when he was minister of religious and public education affairs. After the collapse of the Revolution, due to his activity, he had to leave the country. He wrote his most influential works during his years of exile. Although with origins in the nobility, based on his family's financial status and his father's profession as a physician, we may consider Horváth as someone coming from a bourgeois background, writing rather critically about domestic urban relations, but always with the intent of improving matters.

In order to understand Horváth's opinion about urban and civic development, as reflected in his post-1848 writing, we should first take a look at his book entitled The History of Industry and Commerce in Hungary during the Last Three Centuries (Az ipar és kereskedés története Magyarországban. A három utolsó század alatt) published in 1840. In it, he idealizes Western urban and civic development. Concerning domestic relations, after depicting the underdevelopment of previous centuries and presenting the reasons for backwardness, he enthusiastically

\footnotetext{
${ }^{37}$ On Horváth and his work, see M. Baár, Historians and Nationalism: East-Central Europe in the Nineteenth Century (Oxford, 2010).
} 
welcomes the positive changes of his age. However, upon giving an account of the development of the 1820s and 1830s, he does not connect this welcome progress in any way to towns or burghers. Subsequently, the first four volumes of his huge comprehensive historical overview entitled The History of Hungary (Magyarország történelme) were published in the mid-1840s; later he added another four volumes to cover Hungarian history up to the beginning of the 1870s. However, even in their extended edition these volumes only discuss the events up to the beginning of the Reform Era. In them, towns and burghers are just minor characters; furthermore, they are presented in a rather critical light. Horváth asserts that 'the towns have never striven to closely unite with the rest of the estates of the country; neither have they pursued the same objectives or protected and enriched nationality, constitution and independence, as the other estates have done, with faithfulness and passion'. ${ }^{38}$

Mihály Horváth's most important work regarding our subject, the three-volume Twenty-Five Years of Hungarian History from 1823 to 1848 (Huszonöt év Magyarország történetéböl 1823-tól 1848-ig) was first published in Geneva in 1864. These volumes are the first to summarize the events of his recent past. Their distribution was prohibited by the censors, which naturally contributed to their success and generated wide interest. Based on Horváth's personal experiences, as well as contemporary texts, journal articles and other publications available to him in exile, he compiled this history directly after the events he analysed had taken place.

These three volumes of personal recollections are still among the most frequently cited presentations, reference works and primary sources of the era, whose observations and assessments keep returning in the scholarly literature. Horváth's perspective and approach had a serious impact both on his contemporaries and his later followers, since by the end of his career, he was much esteemed as a leading figure of Hungarian historiography in pursuit of professionalism after 1867. He died as the president of the Hungarian Committee of History, thus his personal reputation reinforced the influence of his work. Based on his The History of Industry and Commerce in Hungary during the Last Three Centuries (1840), Horváth can also be considered as a pioneer of Hungarian economic history writing. Nevertheless, neither in this book about the economy nor in his retrospective work about the Reform Era, did he pay any special attention to towns or burghers. In summary, it is the following quote that best describes his opinion:

In this condition [i.e., in total submission to the government], the towns that should have been the natural flag-bearers of national development, due to their overall limited status, being either led or held on a string, could not fulfil the mission that they were destined for in the course of national transformation; on the contrary, condemned to infancy by the tutelage of the Royal Court, they had an obstructive role in almost everything in the development of the nation. ${ }^{39}$

\footnotetext{
${ }^{38} \mathrm{M}$. Horváth, Magyarország történelme (Budapest, 1873), 60-1.

${ }^{39}$ M. Horváth, Huszonöt év Magyarország történetéböl 1823-tól 1848-ig, 3rd edn (Budapest, 1886), $335-6$.
} 
The next significant author concerning our case is Béla Grünwald, whose personal career was less fortunate. Unlike Horváth, he did not become an influential person of authority by the end of his life; he committed suicide when both his political and academic career seemed to have been halted. Nevertheless, he received academic membership for The Old Hungary 1711-1825 (1888), which discussed the period starting with the end of Ottoman rule and finishing with the Congress of Vienna, in the year of its publication. ${ }^{40}$ His basic argument is that the period was characterized by decline, foreign rule and the lack of an independent political life. He considered the quality of relations with the Austrian hereditary lands and the nature of the constitution of estates, the unfavourable economic-social development, in other words, the missing Hungarian bourgeoisie, as the main reasons for the downturn. For Grünwald, one of the major reasons for the country's economic and social underdevelopment was that 'the organism of the nation was incomplete, an important part, namely towns and burghers, was missing, which were artificially created by the colonization of foreign elements'. This spawned several problems: 'The weakness of the reign originated from the unlimited power of the aristocracy, which was not compensated by a strong bourgeoisie. ${ }^{41}$ Grünwald added that this foreign, weak and unpredictable bourgeoisie, which was alien to domestic national identity, also prevented the formation of a unified Hungarian culture to withstand external oppression. He argued that in the absence of a national bourgeoisie, in Hungary the liberal part of the nobility was supposed to fight for democratic ideas and institutions without the support of the bourgeoisie.

As we can see, Grünwald attributed serious consequences to the foreign origins of the bourgeoisie, which he regarded as explaining the problems of domestic urban development. He saw it as rather immature in comparison with Western trends, which he considered ideal:

When we look at the medieval map of Europe, we can see that Italy, France, Spain, Germany, and England have plenty of rich and enormous towns...; the education of the nobility can only be raised to a higher level when they move into cities and reside there permanently...; the citizenry creates literacy, and the entire spiritual wealth of humanity is the result of the work and culture of this urban element...; in the time of their flourishing, towns become significant political factors, and can achieve a standing worthy of independent, powerful countries... Now, if we look at our homeland, in vain do we search the body of our nation for this powerful factor, this organ indispensable for the advanced economic and spiritual work...And this huge difference is rooted in the fact that the bourgeoisie in Hungary did not grow out of the nation itself but was artificially created by the colonization of foreign elements, who, aside from a few exceptions, did not later blend into the body of the nation. Hungary had a bourgeoisie, although not as significant, rich and powerful as in Europe, but this bourgeoisie was not Hungarian. ${ }^{42}$

\footnotetext{
${ }^{40} \mathrm{~B}$. Grünwald, A régi Magyarország, 1711-1825 (Budapest, 2001).

${ }^{41}$ Ibid., 425-6.

${ }^{42}$ Ibid., 34-5.
} 
The spirit of this reasoning matches the criticism concerning towns and their burghers, present already in the 1840s. Interestingly, Grünwald's formulation resembles the speech quoted from the debates at the 1843-44 parliament concerning the legal standing of towns, reiterating the contemporary noble opposition's widely shared opinion. As Grünwald did not use notes, we can only assume that when writing his book he was using and citing directly the relevant parts of parliament's protocols. However, it appears that he also revisited certain critical assessments that were already present in the Reform Era.

The first huge, multi-authored representative enterprise of official Hungarian historiography, conceived for the celebration of the millennium of the Magyar conquest of the Carpathian Basin in AD 895, was The History of the Hungarian Nation, comprising 10 volumes with Sándor Szilágyi as its general editor. The volume discussing the period between 1815 and 1847 is the work of Géza Ballagi. Similarly to Mihály Horváth's previously cited The History of Hungary, despite its size, this undertaking contains practically no reference to towns and burghers. On the rare occasions when it does address the subject, it repeats Horváth's statements, although in a slightly more sophisticated and permissive manner. For example: 'The burghers of foreign descent did not feel the need to blend into the corporate nation, to become Hungarian, and even if they did show some willingness, the nobility rejected them. ${ }^{, 43}$

Ballagi presents an image of the towns and burghers of the early nineteenth century, generally based on Martin Schwartner's overly critical description quoted above. He highlights the fact that industry and commerce were primarily practised by foreigners, namely the German bourgeoisie. Hungarians, 'even if they could reconcile their pride and their involvement in any craft', were still simple craftsmen producing for the local market at most. ${ }^{44}$ Thus, as in the works of Mihály Horváth and Béla Grünwald, burghers' foreign ancestry is strongly emphasized. Apart from this issue, Ballagi mostly deals with the parliamentary votes given to towns, as well as with the debates concerning the towns' political standing, which he presents from the contemporary liberal nobility's viewpoint, the perspective he embraced himself.

The last great historical synthesis in the period prior to World War I is the twovolume The History of the Hungarian Empire by Ignác Acsády, published in 190304. Acsády was one of the most innovative historians of his age with his pioneering research in the field of economic history and historical demography. The perspective of his monumental work is defined both by his strong nationalism and his antipathy toward the Habsburgs. In the chapters dealing with the period up to the end of the eighteenth century, he gives detailed descriptions of town development. Surprisingly, however, in the section discussing the first half of the nineteenth century, there are even fewer references to towns than in the work of previous authors. Acsády does not give an account of the political debates of the Reform Era regarding towns, thus there is no mention of the contemporary criticism of the bourgeoisie concerning their foreign descent. However, he regarded the ethnic composition of towns as a far from negligible factor. On the contrary, this issue is constantly emphasized, starting from the first town foundations in

\footnotetext{
${ }^{43} \mathrm{G}$. Ballagi, A nemzeti államalkotás kora (1815-1847). A magyar nemzet története IX (Budapest, 1897), 478.

${ }^{44}$ Ibid., 64.
} 
the early Middle Ages. He assumes critically that Hungarian towns started to separate themselves from the 'nation', and that by the early sixteenth century the majority of towns had been 'taken over by the Germans'. According to his analysis, however, the Habsburg economic policy - due to its damaging effects on Hungary - brought a change: 'The damaging effect of this system had an impact on every economic class...All of them were realizing that they had to unite with the Hungarians against their mutual enemies. Thus, the influence of this Hungarian-spirited national identity had a growing influence upon them. ${ }^{45}$

Acsády's narrative concerning the first decades of the nineteenth century suggests that the idea of 'the liberty of the nation' and economic and cultural progress, as well as the struggle for the country's independence, led by the liberal nobility, influenced a growing number of people. This endeavour can explain why in this part of his work, he avoids emphasizing the foreign ancestry of contemporary burghers. Instead, he makes several allusions to the increasing number of non-Hungarian-speaking citizens 'under the influence of the idea of nationality' and also pays special attention to the blending of the Jewish population into the Hungarian nation, acknowledging their economic achievements (Acsády himself was of assimilated Jewish descent). Thus, in the same way as in former history writing, in Acsády's work as well, the image of towns and the bourgeoisie is fundamentally influenced by national narratives.

\section{Conclusion}

As this analysis has shown, the post-revolution historical representation of the burghers and towns of the Hungarian Reform Era was apparently the continuation of previous discourses, hardly extending their framework. The direct source and forerunner of this image - created during the first period of the professionalization of Hungarian historiography - was the perception of towns and their populations in the political debates of the Reform Era. However, the secondary school textbooks and definitive works on Hungarian history published in the era of Austria-Hungary do not treat the analysis, explanations, political statements, protocols of debates in the parliament of the first half of the nineteenth century as mere sources. Instead, they reiterate their assessments without any reflection or significant modification, assessments, which as we have seen, were formulated in a given political context, in political debates and conflicts of interest.

According to Vera Bácskai, in the late nineteenth century the creation of the Hungarian middle class was an important pursuit,

because the nobility believed that preserving the nation was their mission, they refused to resign their leading role, and would not give up their disdain of the bourgeoisie, and especially of their significant proportion that consisted of foreign-speaking (German) and extraneous (Jewish) burghers...; they actually wanted to create a middle class out of the nobility. ${ }^{46}$

\footnotetext{
${ }^{45}$ I. Acsády, A magyar birodalom története, vol. II (Budapest, 1904), 559.

${ }^{46}$ Bácskai, 'A régi polgárságról', 35.
} 
This discourse, with its negative image of burghers, 'remained almost unchanged up to the first decades of the twentieth century, although meanwhile the numbers of the bourgeoisie had also risen significantly, and the process of assimilation had been advanced'. Bácskai's final conclusion is that beyond the reasons introduced in the introduction to the present study 'these discourses about the middle class still have a perceptible influence on the negative image of the old (and modern) bourgeoisie in historiography'. ${ }^{47}$ It should be added that in the Communist period, research about the bourgeoisie was not, to put it mildly, a favoured topic, and even if excellent work was done, the negative and schematic discourse of official Marxist historiography concerning burghers, the bourgeoisie and the cities could not be substantially modified. ${ }^{48}$ Only recently has the revision of the historical assessment of the bourgeoisie been started, in which Bácskai played a pioneering role. This study contributes to this undertaking by analysing the historical discourse about burghers in the age of Austria-Hungary. In conclusion, it appears that the longevity of the negative historical representations of burghers in Hungary can be traced back to two main reasons. One is the influence of nationalist discourses, whose roots go back to the early nineteenth century and which assessed the bourgeoisie based on the ethnolinguistic national discourse. The other is the impact of Marxism, which, however, should be the subject of another study.

\footnotetext{
${ }^{47}$ Ibid., 35.

${ }^{48} \mathrm{G}$. Gyáni, 'Mai várostörténet-írásunk: teljesítmény és irányzatok', in C. Sasfi (ed.), A társadalomtörténet-írás helyzete hazánkban. Ipar és társadalom a 18-20. században (Salgótarján and Budapest, 2003), 35-7.
}

Cite this article: Czoch G (2022). The origins of the negative historical representations of burghers in Hungary. Urban History 49, 502-522. https://doi.org/10.1017/S0963926821000286 